
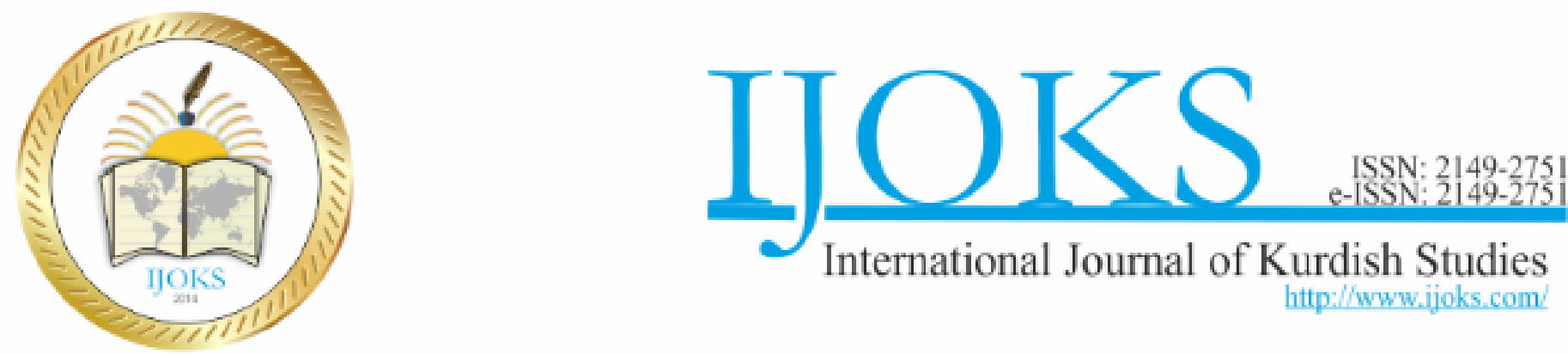

Article

\author{
International Journal of Kurdish Studies \\ 7 (2), pp. 180-205 \\ http://ijoks.com
}

\title{
Perspectives of Sunnites on the Foreign Policy Making Process of Iran Balochis and Kurds ${ }^{1}$
}

Mohammad RIGIDERAKHSHAN ${ }^{2}$ (D)

Received: March 25, $2021 \quad$ Reviewed: May 5, $2021 \quad$ Accepted: May 31, 2021

\begin{abstract}
This paper sets out to explain Iranian and Islamic identities that play a critical role in Iran's foreign policymaking, using "constructivism theory in international relations." The aim is to ascertain the impact of Iranian and Islamic identities along with concomitant changes in current policies of the Islamic Republic of Iran. The policies Iran initiated after the 1979 Revolution focused on the relevance of Islamic identity, and also the need to export the Revolution; this will be examined from a socio-economic and socio-cultural viewpoint. In this context, semi-structured interviews were conducted with Sunni Kurds and Balochi Iranian participants, and the data obtained was analyzed using "content analysis." Iranian Sunni Balochi and Kurdish perspectives on Islamic, specifically Shiite, and also Iranian identity, all three of which gained importance in Iran's foreign policy from 1979 onward are assessed.
\end{abstract}

Keywords: Iran's Foreign Policy, Iranian identity, Islamic identity, Shiite identity, viewpoints of Sunnite Balochis and Kurds

\section{Recommended citation:}

Rigiderakhshan, M. (2021). Perspectives of Sunnites on the Foreign Policy Making Process of Iran Balochis and Kurds. International Journal of Kurdish Studies 7 (2), 180-205, https://doi.org/10.21600/ijoks.902844

\footnotetext{
${ }^{1}$ This article is produced from the writer's PhD thesis.

2 Ph.D, General directorate of immigration administration, Iran: rigi.derakhshan@gmail.com, ORCID: https://orcid.org/0000- 0003-1495-6284
} 


\section{Introduction}

When Iran's foreign policy is examined from 1979 to the present day, it can be seen that it has been built on certain identities such as Islamic identity, Iranian identity, and Shiite identity. Over time, each identity has been prioritized over the other two. As these identities play a role in Iran's foreign policy-making, constructivism theory in international relations is thought to be appropriate to explain how these identities determine Iranian foreign policies. Iranian national interest is based on identities and also shapes them. When the identities are analyzed in accordance with constructivism theory, it will be clear that policies are generated by the differences in the internal dynamics of the subject country. While determining the policies, distinctions can be grouped as "I/other" or "friend/enemy." Identities formed taking into account these distinctions according to the constructivists constitute the socio-cultural structure. On this basis, one cannot talk about identity without constructing the "other" (Waltz, 2015: 56.) Based on this approach, this paper will try to explain the origins of the identities that have contributed to Iran's foreign policy since 1979, through elements in the domestic structure.

Contrary to scholarly works of the pre-1990's on Iran's foreign policy, new generation researchers have attempted to interpret the process of foreign policy-making in the light of the internal dynamics of Iran. The main argument put forward with the new approach is that Iran cannot be understood only through external factors, and that foreign policy is shaped by internal dynamics. Therefore, it is concluded that Iran's foreign policy is fueled by various internal dynamics (Dehghani \& Nouri, 2012: 69.) Within the scope of the study, it becomes clear that Iran's history, geo-politics, and Islamic and revolutionary discourses are at the heart of the identities that feed Iran's foreign policy. While examining the identities that shape foreign policy due to the internal dynamics listed within the scope of the study, the perspectives of Balochis and Kurds, who are Sunni ethnic groups in Iran, and living in different parts of Iran (Babayiğit, 2021; Karacan \& Babayiğit, 2017), have been comprehensively covered.

Face-to-face interviews were held with Iranian Sunni Balochis and Kurds, and the data obtained from these interviews was analyzed using the content analysis method. This paper overall sets out to ascertain viewpoints of the Balochis and Kurds concerning the foreign policy-making processes, and the power of their influence on the foreign policy of the 
Islamic Republic of Iran; this is done by focusing on the historical backgrounds of agents such as Iranian and Islamic identities, geo-politics and Shiite Crescent identity, and the export of the Revolution.

The conclusion reached is that Iran, in the process of establishing the Iranian identity and nationalism that would govern its foreign policy employed strategies that referenced Iran's ancient past. Moreover, when Islamic identity and especially Shiite identity entered the picture, it can be readily understood that what followed would be an intense rapprochement with other Muslim countries.

\subsection{Theoretical Framework}

Separatist nationalist conflicts, which have been noticed for many years but have had a global impact especially with the Cold War, have deeply affected the discipline of international relations. According to Alexander Wendt, one of the pioneers of the theory of constructivism, individual-centered and materialist traditional theories have failed to make sense of these changes in international relations in an atmosphere dominated by ethnic, cultural and religious conflicts, (Wendt, 1999: 4). Thus, in the last years of the twentieth century, the theory of constructivism led to the realization that international relations and foreign policy-making rules should be revised. While Nicholos Onuf introduced the concept of constructivism to the literature, Alexander Wendt developed this concept and presented it as an alternative to the existing theoretical approaches in the discipline of international relations in the 1990s. The British School's approaches to the international community were utilized in explaining international policies in the light of constructivist theory while providing resources for cultural and social structures (Linklater, 2013, p. 123-153).

Constructivism theory has turned to the questioning of the basic concepts of realist theory. While criticizing the concepts of power, for example, national interest and balance of power, it focused on the cultural and social dimensions of international relations and foreign policy with new analyzes. In this sense, the impact of the ethnic and sectarian identities of social groups on politics and contribution of their role against the priority of the state identity are mentioned. Alexander Wendt, stating that all theorists are aware of the importance of power in international relations, draws attention to the fact that the view that relations are shaped by power is not unique to realist theorists. Wendt claims that the interests of the state are formed by intellectual factors and that these intellectual factors form the basis of material 
power and that realists regard power as merely brute force (Social Theory of International Politics, 2016).

Although constructivism is an ascendant theory among international relations theories, there is not a single constructivist theory. Jeffery T. Checkel divides constructivism theory into three; interpretive, traditional and critical / radical constructivism. The theory of interpretative constructivism, which is more prominent in Europe, focuses on discourses and reconstructs the identity of the state with the method of induction by asking the question of "how", unlike the rationalist structural realism and neoliberalism theories that focus more on the question of "why." Critical / radical constructivist theory also emphasizes the importance of discourses, as in interpretive constructivism, and addresses the domination of language over power. Traditional constructivism on the other hand, mostly discussed among American intelligentsia, aims to build a bridge between positivism and post-positivism. Traditional constructivism examines the effects of identity and rules on identity-based changes in international relations (Checkel J. T., 2004: 230-231).

Reus-Smit examined the theory of constructivism under three headings, dividing it into holistic, systemic, and actor-centered. Focusing on the interaction between states, systemic constructivism provides a system-level approach and revolves around the interaction of states in international politics by ignoring the internal dynamics of states. Holistic constructivism theory addresses itself to both national and international politics. It concerns with the identity and interests of the state as a whole, examines the interaction of the state and the international system. Actor-centered constructivist theory, unlike systemic constructivism, puts the internal structure of states at the center, leaving the interaction in international politics in the background. The actor-centered constructivist theory, which deals with the relationship between identities and interests of the states, explains the changes in the foreign policies of the states by taking into account the factors in the internal structure (ReusSmit, 2013: 285-314). Stefano Guzzini identifies constructivism theory as the social construction of knowledge in epistemological terms and as the construction of social reality in ontological terms (Guzzini, 2000:147).

Constructivism enables social identities and social tendencies to develop and spread through the impact they have on the formation of social institutions. Contrary to what was previously described, analytical interests, as they are the output of social relations, are not 
only related to the operation, cooperation or conflict between states, nor are they linked to the distribution of power (Gevam, 2007: 91-104). In addition to its emphasis on the specific structure and configuration of the state concept, the constructivist approach is about a state's identity being not only a psychological or individual problem, but also a relational one. The identity of the state through a social process appears, evolves and can change as a result of the interaction of other state actors with each other. Identities become institutionalized depending on the conditions and reciprocal processes immanent in an established structure. Cultural elements shape national interests accordingly (Hopf, 1998). Hence, identities constitute the origins of national interests (Wendt, 1992: 391-425).

Often, the national identity and identity of states are formed in connection with other nations and states. The identity of states can change depending on their cultural, social, historical and political conditions. Therefore, although these identities are constantly interacting and communicating with each other, in times of international crises and drastic changes, they intensify. (Keremi, 2004: 1-37.)

Another important point to note in constructivism is that ethnicity and race, which are inevitable factors in the structure of society, are inherently affected by the structure and understanding of the state power. For that reason the origins of ethnic conflicts are in the economic and political practices of societies. As for the origins of social conflicts, they are disseminated by, economically and politically speaking, the "elite." Yet socially speaking, elite identities are not inherent and unchangeable. This is only a means of securing economic interest and political power (Biersteker \& Weber, 1996).

According to constructivism theory, what mainly determines the behavior of states in foreign policy is identity. States' interests are shaped in conjunction with their identities. In other words, identities are the basic element underpinning the interests. Based on the above constructivist perspectives regarding the origins of Iranian national identity, and the viewpoints of Iran's Sunni ethnic peoples about these origins as well as the role of the Sunni ethnic population in the formation of national identity - the internal structure factors with an emphasis on constructivist theory will be explained. With the concepts of constructivism theory, this study will delve into how the characteristics of the Sunni ethnic masses affect Iran's foreign policy and discuss the behavior of political actors at the level of analysis. In this regard, the role of the Sunni ethnic masses in the building of Iranian foreign policy and their 
perspective on the foreign policy-making process will constitute the main subject of the study.

When the relationship between identity and foreign policy is examined, it will be seen that they directly affect each other. Whereas identity and environmental structure directly affect the determination of national interests, these factors emerge as also being effective in determining national interests and foreign policy. That is, whereas identity, national interests and environmental structure together make foreign policy; foreign policy can impact on the environmental structure under certain circumstances. The factor that foreign policy can affect would be environmental structure; the environmental structure plays a role in shaping national interests and identity.

According to constructivism, it is the distinctions between some elements within the bodies of states that form identities. These distinctions can either be in the form of "friend /enemy" or of "self /other." Constructivists argue that the identities constructed by the perspective of "self" and "other" make up the socio-cultural structure. With this approach, it is not possible to refer to identity without constructing the other. Identification can be mentioned as a result of the relationship between self and other. (Waltz, 2015: 56) Based on this, the perspective of the Sunni people in Iran towards the process of foreign policy-making and their foreign policy identity is to be analyzed.

\section{Literature Review}

Numerous books and articles have been written in an attempt to understand the characteristic features of Iran's foreign policy. Among the people who wish to get a handle on Iran's foreign policy in line with theory of constructivism and with the help of new internationally circulated theories are names such as Homeira Moshir Zadeh, Seyed Jalal Dehghani Firouz Abadi, Rahman Ghahremanpour, Ahmad Naghib Zadeh, Ebul Kasım Taheri and Nasir Hadian. This study references studies that try to explain Iran's foreign policy through the theory of constructivism. In addition, miscellany on Iran's foreign policy identity will also be used.

In this context, Ahmad Naghib Zadeh (2002), in his book entitled Tesire Ferhenge Milli Ber Siyasete Hariciye Cumhuriye İslami Iran studies Iran's foreign policy on the basis of identity and culture and shows an approach close to constructivism theory. Rahman 
Ghahremanpour (2015) with his Huviyet ve Siyasete Harici Der Iran ve Havermiyane in which he purposes to show how a state would use its identity to construct its own foreign policy, explores how a special identity is constructed and then promoted. Ghahremanpour sought to answer the question of how this identity changed for the duration of domestic and regional conflicts, and how it manifests itself in foreign policy. He mainly researched the export of the Revolution and neo-Islamic groups in Iran. Homeira Moshir Zadeh (2006) too in her article "Tahlile Siyasete Hariciye Cumhuri Islami Iran Ez Menzere Sazengari" analyzes Iran's foreign policy according to the theory of constructivism in a theoretical framework based on Iran's export of the Revolution and Islamic identity based on notions of adalet and mustazaf (justice and vulnerable), but again she too paid no attention to practical considerations. Another name who examined Iran's foreign policy in terms of constructivisim is Dehghani Firouz Abadi 2009 in his article entitled Huviyet ve Menfaat der Siyasete Hariciye Cumhuri İslami İran.

In the book Siyasete Kharici Cumhuri İslami Iran der Devrane Usulgerayi, co-writers Seyyed Jalal Dehghani ve Vahid Nouri (2012) looked into Iran's foreign policy during Ahmedi Nejad's term of presidency of Iran. They analyzed the nuclear diplomacy, counterIsrael policies, and Latin American, African and Asian policies of the Islamic Republic. Alireza Azghandi (2016) in his book Siyasete Harici Cumhuri İslami İan Charchupha ve Cehetgiriya studies Iran's changing pro-revolutionary foreign policy in terms of its political and economic spheres. The writer observes that Iran had pursued a realist foreign policy and replaced it with an idealist stance. According to Azghandi, Iran's foreign policy has diverged from strategic and national interests to transform into an ideological and religious one.

Telhami and Barnett in their book Identity and Foreign Policy in the Middle East claim that Iran's identity consists of three elements: A nationalism dating back to the days of Riza Shah and Mosaddegh that are grounded in Persian history turning almost a blind eye to Islamic identity; a Shiite Islamic identity intending to ensure justice, redefined by Ali Shariati in 1960s and 1970s and anti-imperialism in the face of the colonialism suffered by Iranians (Telhami \& Barnett, 2002). Mahmut Seriyulkalem in his works states that attributes of Iran's foreign policy are ideological based on religious identity. Alireza Azghandi in his work entitled Siyaset Khariciye Cumhuri İslami Iran states that the foreign policy of the Islamic Republic of Iran has been based on two basic identities since the Revolution, namely, Islamic and Iranian, and that these identities have taken a wavering path throughout. 


\subsection{The Identity Characteristics of Iran's Foreign Policy}

Although for a long time foreign policy practices have been interpreted by looking at only external variables in international relations, new generation researchers are challenging the matter by means of internal dynamics. This new perspective states that internal dynamics are the fundamental facets forging foreign policy. In this context it would not be appropriate to evaluate Iran's foreign policy only through external reasons. Therefore to make sense of Iran's foreign policy, Iranian national identity should prove to be decisive. This identity is fed by various sources (Dehghani \& Nouri, 2012: 69). Its origin is based on the sociological, cultural and political values of the Iranian people. These values are the most important elements that distinguish the Iranian people from other populations.

The principal aspects supporting the roots of Iran's foreign policy are its history, geopolitics, Shi'a Islam and the Iranian Revolution discourses. These directly affect Iran's foreign policy. The desire to change the world system and the idea of transmission of the Revolution are also reflections of the rudimentary factors listed. When the Islamic Republic of Iran is in question, distinguishing it is its Islamic identity as well as norms and values that are observable in Iran's foreign policy. Islamic identity is the basic identity of the Islamic Republic of Iran. The basic element that determines the goals, strategies and benefits is the Islamic identity (Museffa \& Novruzi, 2010: 21-23). Motifs such as Islamic culture, Islamic law (fiqh), and Islamic ethics determine the Islamic identity of the Islamic Republic of Iran. According to an Islamic point of view, international systems and states are not divided and formed in relation to nations but rather in relation to their faiths. Accordingly the world is divided into Dār al-Kufr and Dār al-Islām, the former denoting the lands where Islamic law prevails while the latter indicates non-Islamic lands. It is according to the future vision of this approach that the Islamic Ummah Union (Pan-Islamism) will be established. To establish such a union is one of the top purposes of Iran's foreign policy (Museffa \& Novruzi, 2010, s. 21-23).

Iran's foreign policy identity can, Rahman Ghahremanpour maintains, be detected in the speeches of its leaders, the ideology of the Islamic revolution, and its strategic decisions. Ghahremanpour names Iran's foreign policy identity, political Shiite Islam, Velâyat-e Faqih (the doctrine of guardianship), cultural independence, indigenous circumstances, Iranian 
people's embrace of the revolution, anti-imperialism and anti-western sentiment, the demand for justice, as the elements comprising the country's foreign policy character. (Ghahremanpour, 2015). According to Dehghani Firouz Abadi, the elements that make up Iran's foreign policy identity are Iran's history, Iran's geopolitics, the Shi'a, and the Iranian Islamic Revolution discourses (Dehghani Firouz Abadi \& Nouri, 2012: 70).

Islamic references influencing Iran's foreign policy are seen in Iran's constitution too. It is stated in Article 152 of the Constitution that all Muslims must be defended against external threats whereas Article 154 declares that the oppressed will be supported all over the world. In Article 11, it is stated that all Muslims are one Ummah and the Islamic Republic of Iran is obliged to gather all Muslims under one roof (Iran, 1989).

Ibrahim Muttaki and Hucceti Kazimi think the historical consciousness of Iranians, Islamism and concepts belonging to fiqh, and historical experiences of contemporary Iranians is what are behind Tehran's diplomacy guise. (Muttaki \& Kazımi, 2007: 209-237). The fact that mullahs got to have a say in the political sphere following the 1979 Revolution paved the way for the formation of an evident Islamic identity in the nation's foreign policy. The mullahs are the decision-makers on what complies with the foreign policy and what not. There is a similar situation in domestic politics. For instance, while communities of different faiths recognized by mullahs as people of the book (Ahl al-Kitab) have the right to be represented in the assembly, non-Ahl al-Kitab do not. Iran has an officially Shiite administration for its domestic policy. Political and cultural policies are also designed accordingly. The Islamic Ummah understanding though in foreign policy creates a paradox in domestic politics. Article 115 of the constitution stipulates only a Shiite candidate may run for presidency (Ghahremanpour, 2015: 178-179).

According to Hosseinbor (1984), in the wake of 1979, revolutionaries in Iran wanted to attract minorities. Yet with Shiism becoming the official denomination of Iran, Balochis, a Sunni people, have opposed the regime (Hosseinbor, 1984: 171). Sunni Kurds have reacted similarly. Nine days after Shi'ism was pronounced the official denomination in Iran, Sunni Kurds began revolting against revolutionary groups in the city of Negde in the Kurdistan Region (Celayipur, 2001). Hamid Ahmedi claims Sunni ethnic groups started developing a negative perspective towards the revolution; after the Shiite identity was adopted, especially its Jafari branch, the official denomination had the upper hand in Iran's domestic policy 
(Ahmedi H., 2003: 52-55). Moreover, after the revolution, discomfort and discontent arose between the Sunni minorities and the regime, both because of the foreign policy identity of Iran and because of the passive role of Sunnis in domestic policy (Kylmcka, 2002). The fact that only Shiite Iranians could attain to certain offices, as the constitution dictates, is one of the most important indicators of the marginalization.

\subsection{Perspectives of Sunni Ethnic Groups on Iran's Foreign Policy Identities}

In this part of the study, Sunni groups' perspectives on Iran's foreign policy-making practices were measured via thematic questions directed to the participants using the semistructured interview method. Their approaches towards the identities that shape Iran's foreign policy were analyzed by means of interviews with Sunni Balochis and Kurds in this context. Given that the theoretical approach on which the study is based is among the critical theories, the assumptions that the main structure of international politics is based not only on material but also on social grounds and that these grounds shape not only the actions of actors but also their interests and identities, become noticeable. (Wendt, 2005: 201). According to the critical theorists' approach, the interactions of societies, individuals or states with the system of which they are a part, should be taken into account. The relationship that needs to be dwelled on is what is between the identity characteristics and actions carried out by the actors. Edward Lock states that critical theory leads people to think about their actions and to focus on the strands forging their actions and lifestyles (Lock, 2004: 14-16).

When the questions asked at the interviews are classified in order to clarify the relations of Sunni ethnic groups under the regime and to determine their perspectives on the policies pursued, two main titles emerge: (1) Approaches of Sunni Ethnic Groups to Iranian Identity; (2) Approaches of Sunni Ethnic Groups to Islamic Identity. Each title has content with its own particular code.

\subsection{Sunni Baloch and Kurdish Participants' Approaches to Iranian Identity}

The most significant suggestion of the theory of constructivism is the necessity of acknowledging international relations as a social field and the idea that states are social entities. In this regard, attention is drawn to the political roles of international norms, institutions, rules, cognitive and intellectual elements. One of the main starting points of the constructivists was that they brought a historical and social perspective to the field of international relations. Constructivists, calling attention to the founding role of intellectual 
circumstances in the emergence and formation of the social world, point out the role of ideas that have assumed a social quality in world politics (Küçük, 2009: 776-777).

Again, as the constructivists insistently suggest, states will always be rational, but this does not mean that they will disregard their past experiences, for which reason history becomes important. Likewise abstract notions such as "thought" must be included in the analysis of international relations by neo-liberals and neo-realists that pay attention to actual facts such as "interest" and "power" because the belief systems and perceptions that make up the thought seriously affect the foreign policy making processes.

Societies with deep historical and cultural roots keep their ties with the past alive through various legends and myths, which constitute, for example, origins of the Iranian identity in Iran. For Iranians, who enjoy a collective history and culture, Iranian identity is an epithet acting as a source of historical and cultural elements even today (Eshref, Gnoli, \& Shehbazi, 2017: 147). When the answers to the question asked to the participants to establish the perspectives of Sunni ethnic groups on Iranian identity in Iran are examined, one realizes that the Iranian identity was more manifest in the Pahlavi period and it connoted "Persianism." Following the 1979 regime change, though, Shiite rather than Iranian identity started to determine foreign policy and the latter has varied semantically as well as symbolically.

What was also aimed at through the interviews was to ascertain how the foreign policies pursued were associated with Iranian identity. In so doing, the interviewees' own statements relevant to Iranian identity were cited. Whereas most of the participants expressed their opinions by linking Iranian identity with various events and circumstances, Interviewees 7 and 11 did not express their opinions-concerning his Iranian identity, Interviewee 13 replied: "I have no idea about that."

Individuals, depending on their education, culture, social and economic conditions, prioritize some features at times and others at times in the process of composing their identities, and prefer to ignore other features. There may be radical changes in their preference. What drives these events is that parts of the identity might pose a threat to the particular individual. Thus, this situation cannot be thought of independently of our actions. In this line of thought, it is inevitable that the individual who thinks that their national 
identity is threatened will be driven to promote their national identity. The reason is that if there is a certain hierarchy among the elements that make up the identity, it is not stable. Over time, it can change, transform and pave the way for different behavioral patterns to arise. Therefore, it would be appropriate to talk about dynamism when it comes to identity. Identity is open to change and has a multidimensional structure that is always re-organized. For these reasons, it is claimed that identities should be deemed "ambiguous" (Neumann, 1999: 19).

Comparison is another aspect to note as people tend to compare themselves to other individuals or groups. The making of comparisons affects the development of the individual's social identity; the individual's sense of belonging and attachment to their social identity become stronger if concluding with their belonging to the better group. Every identity is built by internalizing the "other." Especially if this "other" creates a threat or is perceived as a threat, then its role functions as strengthening rather than merely defining the identity. In fact the presence of an external threat strengthens the identity of the social unit. (Övet, 2007: 95). As individuals always tend to see themselves and the groups they belong to in a positive light, the conclusion from the comparison can be discussed objectively on a one-to-one basis. In other words, the objectivity of each evaluation to be made in defining the "other" may necessitate referring to an opposite entity along with it.

On the other hand, societies, just like individuals, will feel safer among their counterparts with whom they share a common language, religion, ethnic origin or culture. Taking the psychological effect into account, creating an identity is almost a biological necessity and appears as a useful element in daily lives. People who put themselves and their environment into different identity groups, be it national, social class, ethnic, or sexual with an "I" and an "other," thus simplify daily life (Mercer, 1995: 229-252).

\section{Methodology}

\subsection{Data Collection and Analysis Methods}

Data was collected with the face-to-face interview method that is frequently used in social sciences. Scanning models are a research approach that aim to describe a past or present situation as it is. The groups subject to the study were interviewed in their own conditions and were defined as they are. The data obtained through face-to-face interviews within the scope of qualitative research was analyzed using the content analysis method. In 
this research paper where the qualitative research method has been used, the data is analyzed by means of a content analysis which also contributes defining and analyzing characteristics of Sunni ethnic groups to Iran's foreign policy. The answers secured from open-ended and two-answer options (yes, no) questions were designed and evaluated under various subheadings. It is a data collection method that is performed by asking questions to the participants / subjects in order to get answers through verbal and often face-to-face interviews on various topics (Babayiğit, 2020; Tavukçuoğlu, 2002).

The aim of the interview is to determine the experiences of the participants in specific subjects, and how they interpret and convey these experiences; and, to make it possible to analyze the cultural, ideological, political and sociological characteristics of the participants through the answers given.

\subsection{Analysis of Collected Data: Content Analysis}

Content analysis, which is a qualitative data analysis method, was used in the analysis of the data obtained by the semi-structured interview method. Considering that the content analysis is used together with the coding method in the process of systematically analyzing various verbal and written materials (Krippendorff, 1984: 13; Babayiğit, et all, 2020), it is understood that this is a suitable method for the analysis of research data in terms of objectivity and systematicity.

Before proceeding with the analysis of the obtained data, the data recorded during the interview were transformed into text, ready for analysis. In order to analyze the content as themes, a code list was created over the interview texts and appropriate data classifications were made for analysis. Contextual variables are given as themes and codes in Table 1 in detail. While codes and themes were generated, the developed codes were labeled as lines, sentences and paragraphs and made ready for content analysis. Thus, an infrastructure suitable for the quantification of data was established. Within the scope of the research, the data obtained as a result of the content analysis of the interviews was included in the study by making direct quotations without making any changes under the themes they are related to. The interviewees are listed in coded form by inserting numbering abbreviated as b.1, b.2., b.3. 
Contextual Variables: Themes and Codes

\begin{tabular}{|c|c|}
\hline a. Themes & b. Codes \\
\hline a.1. Iranian Identity & $\begin{array}{l}\text { b.1. Pahlavi Period Relationship } \\
\text { b.2. National Interests } \\
\text { b.3. Persianism } \\
\text { b.4. Iranian identity-Shiism Comparison } \\
\text { b.5. Is Iranian Identity Visible in Foreign } \\
\text { Policy? Yes, No }\end{array}$ \\
\hline a.2. Islamic Identity & $\begin{array}{l}\text { b.1. Islam As A Disadvantaged Identity } \\
\text { b.2. Islamic Identity and Shiism Relationship: } \\
\text { Shiism Influential, } \\
\text { Both Islam and Shiism Influential, } \\
\text { Islam Influential } \\
\text { b.3. Is Islamic Identity Visible in Foreign } \\
\text { Policy? } \\
\text { Yes, No } \\
\text { b.4. Approach to Islamic Identity: Supporting } \\
\text { Islamic Identity, Not Supporting Islamic } \\
\text { Identity }\end{array}$ \\
\hline
\end{tabular}

\section{Findings}

\subsection{The Visibility of Iranian Identity in Iran's Foreign Policy According to Balochis and} Kurds

The interviewees were asked various questions in order to measure the views of Sunni ethnic groups regarding Iranian perceptibility of identities in Iran's foreign policy. $67 \%$ of the participants stated that Iranian identity is not visible in Iran's current foreign policy, while 20\% said otherwise. 13\% of the participants opted for saying: "I have no idea." Participants' thoughts on Iranian identity in foreign policy, the concepts and historical background with which Iranian identity is associated, and their evaluations of Iranian identity are discussed below. 


\subsection{The Relationship between Iranian Identity and the Pahlavi Period}

The interviewees' responses would clearly show us that they frequently refer to the Pahlavi period when they talked about Iranian identity. They thought that the present-day foreign policy characteristic of Iran and that of Pahlavi period were somewhat different, especially in terms of Iranian identity. The participants referred to the Pahlavi era in relation to Iranian identity because of its being relatively recent; however, the pre-Pahlavi period was also referred to. This is due to the emergence of Iranian identity as a result of the influence of the historicity it carried in the pre-Pahlavi period, as well as the influence of the cultural elements of Iranian society (Eshref, Gnoli, \& Shehbazi, 2017: 223).

Participants voiced their opinions that Iranian identity was dominant under the Pahlavi administration and that this status quo changed with the new republic after 1979. Islamic identity, it was said, has replaced Iranian identity ever since Muhammad Reza Shah was toppled and forced into exile in 1979. Participant 2, who claimed that Iranian identity is only a symbol, stated that Iranian identity does not impact on Tehran's foreign policy. Participant 2, when asked why Iranian identity is in sight in the foreign affairs of the nation, said: "Foreign policy is shaped according to international rules." This assessment highlights the view that international conjuncture is a factor in foreign policy.

Saying that Iranian identity was more dominant under the Pahlavi reign, the participants pointed out that the Shiite-oriented foreign policy that followed in the postRevolution period was more assertive than Iranian identity. Participant 20 said: "Iranian identity had been held in high esteem in Pahlavi foreign policy, whereas that has not so much the case ever since the proclamation of the Republic." As can be seen, a linear relationship between Iranian identity and the Pahlavi period stands out. Moreover, in the wake of the 1979 Revolution priority has been given to Islamic identity over Iranian identity, and it has been said of this: "This reality has roller coastered, but the Shiite perspective has gotten the upper hand in the Iranian foreign policy-making process (p. 3).”

Another rationale behind why the participants favor Pahlavi identity politics is due to the tribes' influence having been minimized to assume a more modern and national stance. Accordingly, Iranian identity at the time did not lean on any tribe or clan; on the contrary, it leaned on a homogenous nation state. That is, Iranian identity was based on a more national 
discourse in the time of the Pahlavi leadership — ethnic and tribal forces remaining mostly ineffective. After the revolution, Tehran's way of thinking underwent a radical change from "state-nation" to "state-Ummah"; in other words, a pan-Islamist vision began to replace nationalist slogans. The participants stated that Iranian identity is holistic with eliminating all ethnic differences in contrast to, they argued, pan-Islamism that constructs a religious "other."

\subsection{The Relationships between National Interests and Iranian Identity According to Balochis and Kurds}

According to the constructivists, states also have interests to protect, just like individuals do, and these interests orient them to act. Wendt, one of the leading social constructivists, also supports the idea to perceive states as having individual characteristics (Wendt, 2004: 289-316). According to Wendt, positioning and making sense of states, which most refer to as institutions or structures, as if they are real actors means more than bringing up a useful metaphor to facilitate analysis. This is because decision-making mechanisms always bring concepts such as "national responsibility," "national interest," or "national need" to the forefront, and thus states become real actors, not just metaphors.

That being the case, it is also possible for the state, which is an institutional indication of the coexistence of millions to act in a contradictory way. However, it is easier to predict the goals and forthcoming steps of states than those of individuals since in a legal entity, norms and rules are usually non-verbal and clarified with formal declarations. Wendt also draws attention to the fact that ecosystems can be extended by legal entities, thus enabling various internal mechanisms to become effective (Wendt, 1999: 221-223). In this context, taking the responses given by the participants into consideration, this study attempted to determine how the angles, adopted by the state as an actor in protecting national interests or in fulfilling national responsibilities, were construed. When the participants' views on Iranian identity examined, there is a direct relationship between the protection and prioritization of national interests in Iran's foreign policy of Iranian identity. Participants showed a positive approach to Iranian identity by stating that Iranian identity serves to protect national interests and grow welfare of Iran. While the participants were asked questions about Iranian identity, Iranian identity was defined as re-penetrating the lands that it did culturally and politically in ancient times and turning the power of Iran's former powerful empires into a soft power and regaining a leading position in the region. they were asked to share. The interviewees assess 
Iranian identity by attributing different meanings to it or deriving different characteristics from it. As the participants pointed out, the conclusion was that a more realistic attitude had been adopted under the influence of the Iranian identity, and that therefore the Iranian economy was stronger during the Pahlavi administration. It is also possible to argue the reverse, as done in recent years. That is, embracing Islamic identity, a more idealistic approach strengthens the economy even more. Islamic identity was brought to the fore and economic relations with Western countries were suspended. In addition, after the revolution, during the Iraq-Iran War, neighboring countries supported the West's sanction against Iran.

Correlating between Iranian identity and national solidarity, Participant 16 said that Iranian identity is an inclusive identification under which all sectors of society can band together: "Iranian identity would help national consensus and integration within the country, if it means that all ethnic groups take part in politics, or maintain political, cultural, and economic relations with all ethnic groups-or develop new relations in the international arena" (p. 16). Supporting this comment, Participant 21 stated that as long as Iranian identity continues to mean assurance of division, it would assure that important opportunities for Iran's national interests were lost.

If a discriminatory policy is not followed against Sunni ethnic groups, these groups can create an advantageous situation for Iran's national security by providing full support for Iran's border security. In addition, these groups can be employed as intermediaries in improving relations with Sunni neighboring countries.

Participant 27 said that Iranian identity cannot satisfy ethnic groups and serve national interests. It reveals the discontent that may arise in terms of parties that do not support Iranian identity due to ethnic divisions; for instance, support is offered to Shiite groups in some African countries, but ethnic groups who should be offered more care due to historical links are neglected. Participants 14 and 24 stated that Iranian identity means "Persian" identity. There is a view that although Iranian identity has somewhat changed under the Islamic Republic, it has on occasion come to be perceived as "Persianism." Participants expressed their opinion that it is not possible to achieve national unity with a foreign policy identity that can be promoted as "Persianism." Stating that a kind of Iranian identity signifying Persianism was sponsored during the Pahlavi rule, Participant 24 asserted that while this identity has turned into a Shiite identity, Iranian identity has come to mean Persianism in Iran's foreign policy. 


\subsection{Sunni Balochis and Kurds' Approach to Islamic Identity}

Forming the new constitutional structure according to Islam following the revolution and naming the new state the Islamic Republic of Iran are important indicators of how decisive Islamic identity became in shaping Iran's domestic and foreign policies. Considering the constitution of the Islamic Republic of Iran, Islamic values and norms gained an advantage and became a decisive key in the making of foreign policy. (Museffa \& Novruzi, 2010: 21-23). Considering the relations of Iran in the region after 1979, it is seen that the Islamic identity is especially highlighted. In line with the Islamic identity of Iran, it has been in contact with certain Islamist groups that are active in the countries in the region.

The Islamic identity, which is based on the understanding of Shi'a Islam, was also secured in the Iranian Constitution. Yet, later on problems with Sunni ethnic groups at home and accordingly with other Sunni Muslim countries abroad emerged (Ahmedi H., 2003: 5255). Kylmcka stated that with the policies pursued after the revolution, Sunni groups were pacified to a certain extent, thus problems arose between Sunnis living in the center and the periphery (Multiculturalism and Minorty Right, 2002: 78).

Participants expressed various opinions about the effectiveness of Islamic identity in Iran's foreign policy. $60 \%$ of the participants said "effective," whereas $37 \%$ of the participants spoke in a negative way. The remaining 3\% said, "I have no idea." The reasons why the participants responded thus are mentioned below. Participants showed different approaches towards Islamic identity in the foreign policy. A fraction from the Sunni ethnic groups took a positive approach towards Islamic identity, while others disapproved of it saying it should not be visible in the foreign policy. Participants against Islamic identity said that in terms of realpolitik Islamic identity would not benefit Iran. They argued that Iran's national interests could not be achieved under the influence of the Islamic identity. On the other hand, some participants argued that this sentiment towards the Islamic identity has developed because of active role of Shi'a in the nation's foreign policy.

\subsection{The Relationship between Islamic Identity and Shi'a in Iran's Foreign Policy}

It can be seen that the participants link the Islamic identity and the Shi'a in Iran's foreign policy. It has been suggested that Shiite decisiveness within the current political structure of Iran is reflected in its foreign policy identity. Between the effectiveness of 
Islamic identity and Shiite identity in Iran's foreign policy, $49 \%$ of the participants stated that Islamic identity is effective. On the other hand, $38 \%$ of the participants stated that the Shiite identity is more noticeable. A portion of $13 \%$ stated that in some cases Shiite is more effective, whereas sometimes a more holistic Islamic identity is pursued in a way that embraces all denominations.

Saying that the Islamic Republic of Iran is neither Islamic nor a Republic, Participant 1 claimed that the regime "does not tolerate" Sunni opponents. This can be given as an example of how the Republic performs towards other Islamic denominations. He added that the "Islamic cooperation" slogan in the early years of the Revolution was frequently uttered and so much so that Ayatollah Montazeri even promulgated the "Week of Wahdat (unity)" in order to promote solidarity among all denominations; however, it only remained a slogan. Participant 1 went on to say: "In addition, the Republic named its capital Tehran "Umm AlQura "3. Sunnis were not allowed to build a mosque in Tehran. The Islamic Republic also mobilized the Shiites in Pakistan and Afghanistan in the 1980s, but this fitna brought about many attacks and loss of life. The Taliban killed Shiites in Afghanistan, and Sipah-e-Sahaba (later Millat-e-Islamia, a militant organization) killed the Shiites in Pakistan. It is also possible to see this fitna in the conflicts between Palestinian groups (P.1). Since that time, permission has not been granted to Sunnis to build a mosque, evidence that the Week of Wahdat has not materialized into action. As can be understood, this situation is of significance especially for Sunnis with regard to assurance of denominational solidarity and justice. Participant 2, who does not comment on the relationship of Islamic identity to the Shiite denominations, said: "Islamic identity is very influential, but only in Iran's foreign policy." Although decisions taken in line with the Islamic identity are not acceptable in international law, it is evident in both Iran's domestic and foreign policy. Iran has not been able to progress in international affairs because of such foreign policy.

Emphasizing that the Shiite identity is more visible and seeming to be supportive, Participant 30 clarified the importance of the politics based on it, as follows: Islamic identity and Islamic slogans affect a very wide area in Iran's foreign policy. One of the reasons for

\footnotetext{
3 "Umm Al-Qura is a doctrinal theory based on a purely Shiite vision that is used to define the relationship between the Islamic Republic of Iran and the Arab world in particular, as well as the Islamic world in general, provided that Iran is the political and doctrinal center of the Islamic world, as this center is under the guardianship and leadership of Muslims around the world." (Safi, 2020).
} 
this is that an Islamic identity is needed in order to be successful in internal politics. It is particularly important to have the whip hand over others in Iran. Another reason is that the Islamic identity, more specifically the Shiite identity, is a foreign policy emblem to support other Shiites in the region and the world. For example, Iranians previously did not know who the Houthis were and where Yemen was. But now everyone Iran does. What is more, those who know and speak about the Houthis are not only religious Iranians. The Islamic Republic of Iran has used the Shiite identity greatly in Syria and also in other countries, especially in Lebanon to achieve success. Islamic groups within Iran welcome Iran's presence in those countries. As for nationalist circles in Iran, they are convinced that Iran is present in those countries for national interests."

Participant 4, who claimed that Iran aims at Shiite population growth by adopting a Shiite identity, said: "The Islamic Republic of Iran promotes its Shiite identity in its foreign policy. It always acts with this identity. Actually the Shiite identity is actively used to increase the Shiite population not only in Muslim countries, but also in non-Islamic countries such as some African countries." Participant 7 stated that the foreign policy of the Islamic Republic of Iran failed because of "Shiite instead of Islamic identity," and argued that the former is aimed to spread Shi'ism: "The Shi'a are influential in Iran's foreign policy. It is an ideological identity. It aims to spread Shi'ism. But in reality, this Shiite identity both fails and causes damage to the national interests of the nation." The participant claims that a foreign policy with a Shiite character does not benefit national interests. In addition, the conclusion reached is that those regimes with religious identity follow a foreign policy under the influence of the same identity. Participant 14, who claimed that Islamic identity causes various problems in Iran's domestic and foreign policy because of "especially the Shiite characteristic it carries," listed the problems as follows: "If the Islamic identity carries the aspects that I have listed for Iranian identity, then it could be ideal. But unfortunately, this identity does not carry the features I have cited. Considerable problems arise especially because of the Shiite identity, which challenges national justice and integration; it creates factional troubles within the country, and also causes problems between Iran and other countries."

"You can never see the Islamic identity in Iran's foreign policy. The only thing you can see is Shiite ideology. With this ideology, it is desired to influence other countries and nations," said Participant 22, who more or less agreed with Participant 23 and 24. The 
assessments made by the participants regarding the Islamic identity show that some of the Sunni ethnic groups attribute a Shiite characteristic to the Islamic identity. While it is stated that the aforementioned identity does not serve Iran's national interests, it is concluded that a foreign policy with a Shiite character is also the basis of the problems with neighboring Sunni countries.

\section{Conclusion}

The Revolution and the Shi'a Crescent are effectual instruments alongside Iranian and Islamic identities in Iran's foreign policy as applied from 1979 onward. The aforementioned factors directly, openly and secretly, affect the opinions of decision-makers. Considering Iran's reflective responses in Iran's foreign policy, the effectiveness or ineffectiveness of these factors emerges. Therefore, it does not seem possible to make accurate analyzes of Iran's foreign policy decisions and processes without understanding the considerations described in this study.

During the time of the development of Iranian identity becoming pivotal under the influence of nationalism in Iran's foreign policy, the strategy of referencing Iran's ancient past has been pursued. When the Islamic identity and especially the Shiite identity began to be prominent, steps of rapprochement with Muslim countries were taken in Iran's foreign policy. In the four decades throughout the period since the 1979 Revolution, one of the main unchanging foreign policy principles of the Islamic Republic has been the prioritization of engagement with populations over and above their governments. Likewise the Islamic Republic has had a preference for communication with international organizations rather than with foreign governments. Confronting Israel and supporting the Islamic Movement in Palestine has been among the primary goals of this foreign policy.

After the interviewing, Iranian identity and approaches of Sunni Baloch and Kurdish participants was analyzed. It is concluded that Iranian identity was more visible and connoted Persianism during the Pahlavi administration. However after the 1979 Revolution, Shiite identity has replaced Iranian identity and become more decisive in foreign policy. Of the participants, $67 \%$ stated that Iranian identity is today absent in the nation's foreign policy, whereas $20 \%$ said the opposite. 
The Pahlavi era, due to its being Iran's recent past seemed to be of special interest to the participants. At the same time pre-Pahlavi era experiences were emphasized in relation to the validity of Iranian identities. What is more, a link was ascribed to the relation between protection and prioritization of national interests in foreign policy. The participants said of Iranian identity that it serves to afford protection for national interests and the growing national welfare. As for the effectiveness of Islamic identity, $60 \%$ of the participants stated that Islamic identity is the foremost identity in Iran's foreign policy. 37\% of the participants stated that that was not so. It can be seen that the participants established a direct link between Islamic identity and Shi'ism in Iran's foreign policy. It has been suggested that the Shi'a's effectiveness in the current political structure of Iran is reflected in its foreign policy identity.

\section{REFERENCES}

Abdi, Z. (2015). Endisheye Tegrib Shii ve Sunni; Siyasete Sünnigerayi Nadir Shah. Feslnamaye Mutalaate Tekhribi Mezayebe İslami, 33-45.

Abrahamian, E. (1981). Iran Between two Revolutions. Princeton: Princeton University Press.

Ahmedi, H. (2003). Huviyeti İrani Bonyadha, Çaleşha ve Rişeha. Pejoeşe Ferhengi (6), 5255.

Ahmedi, H. (2017). Kovmiyet ve Kovmiyergerayi der İran. Tahran: Neşr'e Ney.

Algar, H. (1969). Religion and State in Modern Iran. Berkeley: University of California Press.

Algar, H. (1999). Din ve Devlet Der İran, Nekhshe Ulema Der Doreye Gacar. (E. Sirrı, Trans.) Tahran: Tus.

Aronva, M. R., \& Eşrafyan, K. Z. (1978). Devlete Nadir Şah Afşar. (H. Emin, Trans.) Tahran: Enteşarate Daneşgahi.

Asıf, M. H. (1974). Resm'ul Tevarikh. (M. Müşiri, Ed.) Tahran: Emir Kebir.

Babayiğit, M. V. (2020). What Do English Teachers Keep in Their Notes for the Students? The profits of Field Notes for the Development of Language Skills. 2nd ECLSS International Online Conference on Economics and Social Sciences, 468-471, June 28-29, Istanbul, Turkey.

Babayiğit, M. V., Ateş M. E., Cizrelioğulları, M. N., \& Altun, Ö. (2020). Otonom Öğretmenin Eğitim Ahlakının Gelişiminde ve Eğitim Sorunlarının Azaltılmasında 
Rolü. 10th ECLSS Conferences on Language and Social Sciences, 191-198, 20-21

November, Almaty, Kazakhstan.

Babayiğit, M. V. (2021). Kürtçe, Türkçe ve İngilizce deki Bazı Fiillerin Anlamsal ve Kip Açısından Analizi. International Journal of Kurdish Studies 7 (1), 123-139, https://doi.org/10.21600/ijoks. 850817

Biersteker, T. J., \& Weber, C. (1996). State Sovereignty as Sosyal Construct. Cambridge: Cambridge university press.

Caferiyan, R. (2000). Safeviye Der Erseye Din ve Ferheng ve Siyaset. Kum: Pejoyeshgahe Hoze ve Daneshgah.

Celayipur, H. R. (2001). Camishenasiye Cumbeshaye İctimayi (Ba Tekid Ber Cumbeshe İslahiye Dovvome Hordad). Tahran: Entesharate Terhe Now.

Checkel, J. T. (2004). Social Constructivisms in Global and European Politics: A Review Essay. Review of International Studies, 230-231.

Çalış, S., \& Özlük, E. (2007). Uluslararası İlişkiler Tarihinin Yapısökümü: İdealizm-Realizm Tartışması. Selçuk Üniversitesi Sosyal Bilimler Enstitüsü Dergisi (18), 225-245.

Dehghani, S. J., \& Nouri, V. (2012). Siyasete Harici Cumhuri İslami İran der Devrane Usulgerayi. Tahran: İmam Sadık Universitesi.

Dehghani, S. J., \& Nouri, V. (2012). Siyasete Harici Cumhuri İslami İran der Devrane Usulgerayi. Tahran: İmam Sadık Üniversitesi.

Eshref, A., Gnoli, G., \& Shehbazi, A. S. (2017). Hoviyete İrani Ez Devrane Bastan Ta Payane Pehlevi. (H. Ahmedi, Trans.) Tahran: Ney.

Fischer, M. M. (2006). Culture and Foreign Politics. In B. Shafer, The Limits of Culture: Islam and Foreign Policy (pp. 27-65). London: The MIT Press.

Fransevi, M. B. (2003). Menem Teymur'e Cehangusha. (Z. Mensuri, Trans.) Tahran: Kitapkhaneyi Mostofi.

Gerges, F. (2005). Amerika ve İslam-e Siyasi. Tahran: Mutalahat'e Rabordi.

Gevam, A. (2007). Berresi Sazehengarane Bonyadhaye Siyaset Khareci İran. Khete Avel Dergisi, 91-104.

Guzzini, S. (2000). A Reconstruction of Constructivism in International Relations. European Journal of International Relations, 147.

Hopf, T. (1998). The Promise of Constructivism in International Relation Theory. International Security, 177-200. 
Hosseinbor, M. H. (1984). Iran and its Nationalities: The Case of Baluch Nationalism. Iran and its Nationalities, the Card of Balluch, 171. Washington, Washington, ABD: American University.

Iran, K. E. (1989). Kanune Esasi Cumhuri İslami İran. Tahran.

Küçük, M. (2009). Uluslararası İlişkiler Kuramında Konstrüktivist Dönüşü Anlamak. Ege Akademik Bakış, 9(2), 771-795.

Kadiyani, A. (2005). Tarikhe Ediyan ve Mezayep Der İran. Tahran : Enis.

Ghahremanpour, R. (2015). Huviyet ve Siyasete Harici Der İran ve Havermiyane. Tahran: Rozene Yayınevi.

Ghahremanpour, R. (2015). Huviyet ve Siyasete Harici Der İran ve Havermiyane. Tahran: Rozene Yayınevi.

Karacan, H., \& Babayiğit, M. V. (2017). Türk ve Kürt Dillerinin Sentaks (Sözdizimsel) Karşılaştırması. Tiydem Yayıncılık, Editör: Hasan KARACAN, Basım sayısı, 3, 731.

Kamberi, E. (2012). Tehlili Ber Naberaberi Nayeiye Der İran. Tahran: Pejoeshkedeye Mutalaate Rabordi.

Kasimi, A., \& Tahiri, A. (2016). Cayegaye Mezhep ve Mesayele Fıkhi Der Münasebate İran ve Osmani Der Doreye Safeviye ve Afşariye. Feslnameye Gencineye Esnad , 44-64.

Keremi, C. (2004). Hüviyet ve Siyaset Khareci. Siyaset Dergisi, 1-37.

Kissinger, H. (2002). Amerika'nın Dış Politikaya İhtiyacı Var mı?. (T. Evyapan, Trans.) Ankara: METU Press.

Konukcu, Y. (2018). İran'1n Bölgesel Güvenlik Stratejisi: Bir Güç Döngüsünün Değerlendirilmesi. Bitlis Eren Üniversitesi Akademik İzdüşüm Dergisi, 3(3), 74-91.

Krippendorff, K. (1984). Content Analysis (An Introduction to its Methodolohy). Beverly Hills: Sage Publication.

Kylmcka, W. (2002). Multiculturalism and Minorty Right. Kingston, Kanada: Queen University.

Ladiye, M., \& Fuladi. (2003). Cemiyet ve Siyaset der İran Ez Seltenete Meşrute ta Cumhuri İslami İran. Fransa: Muesseseye Milliye Mutalaate Cemiyetşinasiye Fransa.

Linklater, A. (2013). İngiliz Okulu. In S. Burchill, \& A. Linklater, Uluslararası İlişkiler Teorileri (pp. 123-153). İstanbul: Küre Yayınları.

Lock, E. (2004). International Politics as Politics: Changing US Foreign Policy Discourse. Paper Presented at the Oceanic Conference on International Studies, 14-16.

Malcolm, J. (2001). Tarikhe Kamele İran (Vol. 2). (M. İ. Heyret, Trans.) Tahran: Efsun. 
Mercer, J. (1995, Spring). Anarchy and Identity. International Organization, 49, 229-252.

Mervi, M. K. (1985). Tarikhe Aleme Araye Nadıri . (M. E. Riyayi, Ed.) Tahran : Zevvar.

Mugessigi, S. A. (2003). Rabıteye Din ve Siyaset Der İran (Yer Berresiye Teoirk ve Tarikhi). Mecelleye Daneshketeye Hukuk ve Ulum Siyasi , 239-272.

Museffa, N., \& Novruzi, H. (2010). Negayi Be Siyaset Harici Cumhuri İslami İran. Tahran: İran Dışişleri Bakanlığı.

Museffa, N., \& Novruzi, H. (2010). Negayi Be Siyaset Harici Cumhuri İslami İran. Tahran: İran Dışişleri Bakanlığı.

Mutteki, I., \& Kazimi, H. (2007). Sazengari, Huviyet, Zeban ve Siyasete Hariciye İran. Feslameye Siyaset, 209-237.

Neumann, I. B. (1999). Avrupa Kimliği, AB Genişlemesi ve Entegrasyon/Dışlama Bağıntısı. Avrasya Dosyası, Avrupa Birliği Özel, 5(4), 19.

Niva, S. (1999). Contested Sovereignities and Postcolonial Insecurities in the Middle East. In J. Weldes, M. Laffey, H. Gusterson, \& R. Duvall, Cultures of Insecurity: States, Communities, and the Production of Danger (pp. 147-172,). Minneapolis: University of Minnesota Press.

Övet, T. (2007). Avrupa ‘Öteki’si . TASAM Stratejik Araştırmalar Dergisi (11), 94-103.

Özkan, H. (2019). İran İslam Devrimi'ne Dair Tanımlamalar/Kavramsallaştırmalar: 19781990 Yılları Arasında Türkiye'de Yayımlanan İslami Dergiler Üzerine Bir İnceleme. e-Şarkiyat İlmi Araştırmalar Dergisi , 1282-1299.

Reus-Smit, C. (2013). Konstrüktivizm. In A. Linklater, S. Burchill, \& vd, Uluslararas1 İlişkiler Teorileri (M. Ağcan, \& A. Aslan, Trans., pp. 285-314). İstanbul: Küre Yayınları.

Rigiderakhshan, M. (2011). Berresiye Tetbigiye Zeminhaye Siysesiye Buruze Engelabe Meşrute ve Engelabe Eslami. Berresiye Tetbikiye Zeminhaye Siysesiye Zuhure Engelabe Meshrute ve Engelabe İslami. Tahran, Tahran, İran: Daneshgahe Tahran Merkez.

Safi, B. A. (2020). Shiite Geopolitics Contemporary Shiite Geopolitical Theories and Terms. International Journal of Scientific Research and Management, 1-7.

Shehbani, R. (2005). Tarikhe Tehevvulate Siyasi İçtimaiye İran Der Dorehaye Afshariye ve Zendiye. Tahran: Semt.

Smith, S. (2005). The Contested Concept of Security . In K. Booth, Critical Security Studies \& World Politics. New Delhi: Viva Books. 
Tavukçuoğlu, C. (2002). Bilimsel Araştırma Yöntemleri ve Proje Hazırlama, Değerlendirme Kilavuzu. Ankara: Kara Harp Okulu Basım Evi.

Telhami, S. Z., \& Barnett, M. (2002). Identity and Foreign Policy in the Middle East. London: Cornell University Press.

Vaizi, Z. A. (1970). Bedahe'ul Vekaye. (A. Beldrof, Ed.) Tahran: Bonyade Ferhenge İran.

Valter, H. (1992). Shah İsmaile Dovvome Safevi. (K. Cehandari, Trans.) Tahran: Sherkete Entesharate Elmi ve Ferhengi.

Waltz, K. (2015). Uluslararası Politika Teorisi. (O. S. Binatlı, Trans.) Ankara: Phoenix Yayınevi.

Wendt, A. (1992). Anarchy is What States Make of It. International Organization, 391-425.

Wendt, A. (1999). Social Theory of International Politics. Cambridge: Cambridge University Press.

Wendt, A. (2004). The State as Person in International Relations Theory. Review of International Studies, 30(2), 289-316.

Wendt, A. (2005). Constructing International Politics. Theories of International Relations, 201.

Wendt, A. (2016). Uluslararası Siyasetin Sosyal Teorisi. (H. S. Ertem, \& S. G. Öner, Trans.) İstanbul: Küre Yayınları. 